\title{
PEMAKNAAN SIMBOL REOG PONOROGO DALAM TRADISI JAWA: SEBUAH KAJIAN KRITIS
}

\author{
Meaning of the Ponorogo Reog Symbol in the Java Tradition: A Critical \\ Study
}

\author{
${ }^{1)}$ Dhika Yuan Yurisma, ${ }^{2)}$ Muhammad Bahruddin \\ 1) 2) Desain Komunikasi Visual, Universitas Dinamika \\ 1) 2) Jalan Raya Kedung Baruk 98, Surabaya
}

Diterima 13 Februari 2020 / Disetujui 19 Maret 2020

\begin{abstract}
This research attempts to dismantle the meaning in the Ponogogo Reog symbol by using Javanese tradition studies, both in asthabrata teachings and Javanese cosmogony: keblat papat kelimo pancer. This research is important because not many people understand the meaning contained in the Reog symbols. On the other hand, the Reog symbols are now being reduced by the interests of commercialism so as to eliminate the valuable values in them. This can be seen in the use of Reog symbols which are used as a citybranding media in the city of Ponorogo and performances that come out of the standards Reog tradition. Reog's art has turned into a commodity that is traded to the market. This study uses qualitative methods using a critical paradigm. A paradigm that assesses social reality is not a neutral reality, but is deliberately shaped by and for political, economic, and social interests that are dominated by dominant groups in society by collecting data through observation and in-depth interviews with experts in the field of Javanese culture, specifically about Reog to obtain the meaning of the Reog Ponorogo symbol from Javanese tradition. The results of this study describe the meaning in the Reog symbol and see the development of traditional Javanese art is reduced by market interests. The symbols in Reog Ponorogo have meanings related to lust that exists in humans. Symbolization in Reog's art forms valuable meanings and values in society. in general, Reog Ponorogo is a show that can provide guidance in living life for those who see it or understand it deeply. Reog is no longer an art and culture that requires special rituals in every performance but is commodified into a commercial merchandise. At this stage, Reog's products are adjusted to market demands with market standards as well. Products related to Reog are then mass-produced and even made replicas that resemble Reog.
\end{abstract}

Keywords: Reog, Ponorogo, Symbols, Meanings, Cultural Values, Commodities

\begin{abstract}
ABSTRAK
Penelitian ini berusaha membongkar makna dalam simbol Reog Ponorogo dengan menggunakan kajian tradisi Jawa, baik dalam ajaran asthabrata maupun kosmogoni Jawa: keblat papat kelimo pancer.Penelitian in penting karena tidak banyak masyarakat memahami makna yang terkandung dalam simbol-simbol Reog. Di sisi lain, simbol-simbol Reog saat ini mulai direduksi oleh kepentingan komersialisme sehingga menghilangkan nilainilai adiluhung di dalamnya.Hal ini tampak dalam penggunaan simbol-simbol Reog yang digunakan sebagai media citybranding kota Ponorogo maupun pertunjukan-pertunjukan yang keluar dari pakem-pakem tradisi Reog. Seni Reog berubah menjadi sebuah komoditas yang diperdagangkan ke pasar. Penelitian ini menggunakan metode kualitatif dengan menggunakan paradigma kritis. Sebuah paradigma yang menilai realitas sosial bukan sebagai sebuah realitas yang netral, melainkan sengaja dibentuk oleh dan untuk kepentingan politik, ekonomi, dan sosial yang dikuasai oleh kelompok-kelompok yang dominan dalam masyarakat dengan pengumpulan data melalui observasi dan wawancara mendalam kepada ahli bidang kebudayaan Jawa, khususnya tentang Reog untuk memperoleh makna-makna simbol Reog Ponorogo dari tradisi Jawa. Hasil dari penelitian ini mendiskripsikan makna dalam simbol Reog sekaligus melihat perkembangan seni tradisional Jawa ini tereduksi oleh kepentingan pasar. Simbol-simbol dalam Reog Ponorogo memiliki makna terkait dengan nafsu yang ada dalam diri manusia. Simbolisasi dalam kesenian Reog membentuk makna-makna dan nilai-nilai adiluhung di masyarakat. secara umum, Reog Ponorogo merupakan sebuah pertunjukan yang bisa memberikan tuntunan dalam menjalani kehidupan bagi yang melihatnya atau mengerti secara mendalam. Reog bukan lagi sebuah seni budaya yang memerlukan ritual khusus dalam setiap pertunjukan melainkan dikomodifikasi menjadi sebuah barang dagangan yang dikomersialkan. Pada tahapan ini, produk Reog disesuaikan dengan permintaan pasar dengan standar-standar
\end{abstract}


pasar pula. Produk-produk yang berkaitan dengan Reog kemudian diproduksi secara massal bahkan dibuat replika-replika yang menyerupai Reog.

Kata Kunci: Reog, Ponorogo, Simbol, Makna, Nilai Budaya, Komoditas

*Korespondensi Penulis

Email : dhika@ dinamika.ac.id

\section{PENDAHULUAN}

Kesenian Reog Ponorogo merupakan kesenian tradisional yang sarat akan nilai-nilai adiluhung. Reog sebagai kebanggaan masyarakat Ponorogo tidak hanya berkembang luas di dalam negeri tapi juga mancanegara. Dalam ajaran asthabrata dan kosmogoni Jawa: keblat papat kelimo pancer, Reog Ponorogo memiliki nilai-nilai luhur kehidupan orangorang Jawa. Meski demikian, tak banyak masyarakat yang mengetahui makna-makna di balik simbol-simbol dalam Reog Ponorogo. Sementara di sisi lain, simbol-simbol Reog sudah banyak yang direduksi untuk kepentingan komersialisme sehingga menghilangkan unsur magis dan nilai-nilai budaya dalam Reog. Kesenian tradisional ini telah menjadi komoditas yang berorientasi pada materi. Hal ini tampak dalam program city branding kota Ponorogo yang menghadirkan patung-patung Reog yang banyak ditemui di sudut-sudut kota dengan berbagai media sehingga menghilangkan unsur magis dari keseniaan Jawa tersebut. Selain itu, dalam beberapa pertunjukan Reog juga mulai banyak yang meninggalkan pakem-pakem yang harus dipenuhi dalam menampilkan seni Reog Ponorogo.

Dalam penelitian sebelumnya, peneliti bersama tim (Yurisma et al., 2015) menemukan kesenian tradisional Reog Ponorogo yang kaya dengan nilai-nilai filosofi kehidupan orang Jawa tersebut telah berubah dalam bentuk patung, gapura, maupun unsur visual lainnya. Hal ini merupakan implikasi dari program city branding kota Ponorogo yang tidak disertai kajian mendalam tentang seni Reog, simbolsimbol, dan nilai-nilai Reog yang mendasarinya. Inilah yang menyebabkan keberadaan patung-patung dan gapura tersebut hanya bersifat sebagai elemen estetis penghias kota saja.

Reog Ponorogo mengalami beberapa pergeseran seiring perkembangan zaman.
Setidaknya Reog Ponorogo terbagi dalam Reog festival, Reog obyogan, dan Reog mini. Sebagai produk seni dan budaya, Reog perlu dilestarikan. Oleh karena itu, berbagai upaya dilakukan oleh pemerintah setempat untuk melakukan konservasi terhadap Reog Ponorogo. Dalam hal ini, pemerintah melakukan revitalisasi, reinterpretasi dan ekspresi simbolik. Untuk merevitalisasi Reog Ponorogo, pemerintah mengajak para seniman Reog untuk saling bekerja sama dalam mewujudkan sebagai produk budaya. Maka lahirlah Reog mini dan beberapa kerajinan, serta miniatur-miniatur Reog Ponorogo.

Selanjutnya, pemerintah dan seniman juga melakukan reinterpretasi dan ekspresi simbolik terhadap Reog Ponorogo, seperti Festival Grebeg Suro. Dalam festival ini pemerintah dan seniman mengadakan sejumlah lomba dalam pagelaran Reog. Dalam pagelaran tersebut peserta bebas mengekspresikan segala bentuk inspirasi dan aspirasinya namun tidak keluar dari aturan-aturan yang telah dibuat. Agar secara hukum menjadi kuat, pemerintah setempat telah mengeluarkan keputusan nomor: 188.45/101/405.13/2014. Kegiatan yang diadakan setiap tahunnya ini bertujuan untuk meningkatkan perekonomian rakyat dan turut melestarikan potensi budaya daerah dalam menunjang wisata di Kabupaten Ponorogo.

Festival Grebeg Suro menjadi sangat penting bagi masyarakat Ponorogo karena merupakan kegiatan rutin tahunan yang diadakan setiap tanggal 1 Muharram (1 Suro pada tahun Jawa) dan Grebeg Suro ini bertujuan melestarikan nilai-nilai luhur budaya bangsa, yakni Reog Ponorogo yang merupakan kesenian tradisional asli Ponorogo. Dengan adanya festival tahunan tersebut diharapkan seluruh anak bangsa dan mancanegara memahami bahwa Reog merupakan kesenian asli Ponorogo.

Festival Grebeg Suro di Ponorogo merupakan pesta besar karena semua masyarakat berbondong-bondong untuk 
berpartisipasi dalam setiap kegiatan yang diadakan. Masyarakat Ponorogo ingin menunjukan bahwa mereka sangat peduli terhadap pelestarian seni budaya lokal dan nilai-nilai yang terkandung di dalamnya. Di samping itu, dalam pelaksanaan Festival Grebeg Suro terdapat unsur gotong royong. Tujuan pemerintah daerah yang ingin dicapai dalam Festival Grebeg Suro adalah masyarakat dapat memelihara nilai-nilai religius yang berkembang di Kabupaten Ponorogo dalam menyambut Tahun Baru Islam serta turut serta dalam pelestarian seni budaya tradisional khas Ponorogo.

Grebeg Suro di Ponorogo dapat dilihat dengan adanya tari Reog Ponorogo yang tidak ditemui dalam acara serupa di daerah lain. Dalam grebeg ini juga digelar kirab budaya, pemilihan kakang senduk, serta acara Larung Risalah dan Doa. Prosesi tersebut menarik, tidak hanya dalam format fisiknya, tetapi juga nilai-nilai yang terkandung di dalamnya.

Pada dasarnya Grebeg Suro Ponorogo merupakan suatu acara yang diadakan untuk memperingati datangnya tahun baru Islam (dalam istilah Jawa disebut Suro). Berbagai macam dan tata cara kegiatan dalam menyambut bulan Suro bagi masyarakat Ponorogo adalah bagian dari kegiatan religius. Semua itu dilakukan semata untuk melakukan pendekatan kepada Yang Kuasa. Grebeg Suro maupun kesenian Reog adalah sebuah sarana untuk mendekatkan diri pada Sang Pencipta. Di sisi lain, Grebeg Suro menjadi daya tarik wisatawan, baik dari dalam negeri maupun mancanegara.

Sedangkan kesenian Reog obyogan yaitu kesenian yang hidup di pedesaan tapi banyak meninggalkan pakem Reog Ponorogo. Tempat-tempat pertunjukannya bisa menggunakan halaman rumah, perempatan atau pertigaan jalan desa, serta di pelataran pekuburan. Perbedaannya dengan Reog tradisional adalah pada formasi pemain, musik, dan tempat pegelarannya. Reog obyogan tidak menampilkan karakter Kelana Sewandhana dan Warok. Reog ini hanya menampilkan Dhadak Merak, Jathilan dan Bujang Ganong. Ketiga karakter tersebut selalu menjadi daya tarik bagi masyarakat dengan harapan akan mendapatkan banyak pemesanan pertunjukan secara terus menerus sehingga dari sisi ekonomi dan bisnis bisa menarik banyak modal dan materi (uang).
Demikian juga dengan musik yang disajikan. Reog obyogan menyajikan jenis musik campuran yang didasarkan pada kesukaan masyarakat seperti lagu-lagu dangdut dan campur sari. Pada sisi ini, Reog obyogan identik dengan sawer yaitu menerima pecahan uang kertas dari para penonton saat melakukan pertunjukan. Peristiwa ini mirip dengan pertunjukan musik di dangdut di masyarakat, seorang penyanyi dangdut di-sawer dengan beberapa pecahan uang kertas, kemudian diajak berjoget bersama. Sementara dalam pertunjukan Reog obyogan, para penari Jathilan yang menjadi tokoh utama dijadikan objek sawer. Seorang penari Jathilan menari dengan gemulai sesuai iringan lagu. Sementara penonton banyak yang ikut menari dan nyawer dengan pecahan uang kertas kepada penari Jathilan tersebut. Peristiwa seperti tidak akan ditemui di pagelaran reyog tradisional.

Sedangkan Reog mini merupakan pagelaran Reog yang hampir menyerupai Reog tradisional, mulai dari karakter yang dimainkan, musik, dan lain sebagainya. Yang menjadi pembeda adalah Reog ini dimainkan oleh anak-anak dan remaja. Hal ini merupakan upaya dari para seniman dan pemerintah untuk melestarikan kesenian pada generasi muda. Yang menjadi pembeda lainnya adalah topeng Dhadak Merak yang digunakan dalam Reog mini berukuran minimalis (kecil) karena semua tokoh dalam pagelaran ini di mainkan oleh anak-anak.

Perkembangan Reog saat ini tidak luput dari usaha pemerintah dalam mempertahankan warisan budayanya. Harapannya, generasi penerus tidak hanya dapat menikmati pagelaran ini tapi juga turut melestarikan. Bahkan pada tahun 2019 bupati Ponorogo mengeluarkan istruksi bupati Nomor 556/582/405.08/2019 untuk melakukan pagelaran Reog serentak di seluruh desa di kabupaten Ponorogo pada setiap tanggal 11 bulan Juli.

Nilai-nilai dalam simbol Reog sebagai produk budaya ini penting karena sebuah kebudayaan tidak hanya mampu merepresentasikan identitas dari sebuah kelompok tapi juga sebagai media untuk membentuk sebuah visual dari kelompok tersebut (Lynch, 1960:45).

Nanang Rizali (dalam Dharsono, 2007:24) melihat kebudayaan sarat dengan 
makna, nilai, dan simbol. Menurutnya, pemahaman tentang makna, nilai, dan simbol sesungguhnya sama dengan memahami sebuah kebudayaan yang dijadikan rujukan oleh masyarakat setempat. Oleh karena itu, Mulyana (dalam Hutapea, 2016) menjelaskan bahwa setiap budaya memiliki variasi simbol masingmasing, baik tempat, konteks, maupun waktu. Hal ini yang menyebabkan makna simbol berbeda dari budaya satu dengan budaya lainnya. Atas dasar itu, Charles Sanders Peirce membagi dalam tiga tanda yaitu iconic, indexical dan simbolic. Tanda iconic merujuk pada tanda yang menyerupai benda yang diwakilinya. Tanda indexical merupakan tanda yang dihubungkan dengan benda yang diwakilinya. Sedangkan simbolic merujuk pada tanda yang tak memperlihatkan hubungan alamiah antara penanda dan petandanya. Hubungan antarkeduanya bersifat semena (arbitrer), berdasarkan konvensi masyarakat (Rahmanto, 1992:108)

K. Langer (Langer, 1976:25) membedakan simbol menjadi dua jenis yaitu presentasional, dan diskursif. Simbol presentasional tidak membutuhkan nalar intelektual. Artinya, simbol menghadirkan sesuatu yang dikandungnya secara spontan. Misalnya, simbol pada alam, pahatan, lukisan, tari-tarian, dan lain sebagainya. Sedangkan, simbol diskursif menggunakan cara-cara intelektual dan tak spontan. Namun simbol ini berurutan. Simbol seperti ini bisa dijumpai dalam bahasa yang dikonstruksi secara konsekuen.

Cassirer (1987:81) memaknai simbol lebih luas lagi. Dia menyebut bentuk-bentuk simbolik ada pada bahasa, seni, dan agama. Bentuk-bentuk ini bisa berbentuk bahasa seperti cerita, peribahasa, syair, pantun, atau perumpamaan. Bentuk lambang atau simbol juga bisa berbentuk gerak tubuh atau tari. Selain itu bisa juga berbentuk suara atau bunyibunyian seperti lagu atau musik. Bentuk-bentuk ini juga bisa berupa warna maupun rupa seperti ukiran, hiasan, lukisan, maupun bangunan.

Sebuah kebudayaan tidak lepas dari sistem simbol. Kebudayaan selalu menjadi sebuah acuan maupun pedoman masyarakat yang ditransmisikan melalui kode-kode simbolik. Karena itu makna dan nilai dalam Reog Ponorogo yang terkait dengan artifak seni dan budaya memiliki makna simbolis yang memiliki nilai-nilai filosofi Jawa.

Menurut Simuh (Dharsono, 2006) kebudayaan Jawa kaya akan simbol-simbol atau lambang-lambang karena pada zaman dulu, orang Jawa terbiasa menyampaikan simbol-simbol yang lebih konkret untuk menyampaikan ide dan gagasannya. Saat itu Orang Jawa tak terbiasa berpikir secara abstrak. Keberadaan Reog Ponorogo adalah bagian dari hasil kebudayaan di Jawa. Keberadaan tersebut memberi gambaran tentang adanya hubungan antara makrokosmos dan mikrokosmos. Oleh karena itu diperlukan kajian tentang simbol dan makna Reog Ponorogo tersebut dengan tata susunannya dalam berbagai media ekspresi kebudayaan Jawa.

Secara tersirat, ajaran filsafat Jawa menegaskan hubungan mikro-makrometakosmos sesuai sistem berpikir budaya mistis Indonesia. Pandangan ini berkaitan dengan kedudukan manusia sebagai bagian dari semesta. Seorang manusia harus sadar tentang tempat dan kedudukannya di alam semesta ini.

Terkait dengan kajian suatu desain sebagai bahasa rupa, desain dianggap sebagai alat komunikasi dalam menyampaikan berbagai macam gagasan atau ide. Reog merupakan sebuah kesenian yang memiliki banyak karya desain, mulai dari tata rias, pakaian, dan topeng. Reog sebagai bahasa rupa yang mengandung makna tanda dan merupakan objek kajian spesifik yang perlu ditelaah lebih lanjut untuk mengetahui alasan mengapa Kabupaten Ponorogo menggunakan Reog sebagai citra kota.

Durkheim (dalam Milawaty, 2019) menyebut bahwa dalam menjaga kelestarian komunitasnya sendiri, masyarakat berupaya menjalin hubungan erat dengan sebuah kepercayaan lokal setempat.

Meski demikian, simbol tidak bisa dilepaskan dari kelas dominan. Dalam tradisi Marxis, penekanan besar dalam simbol adalah fungsi politik dari sistem simbol (Bourdieu, 1991:166). Karena itu, tergerusnya simbol Reog oleh nilai-nilai tertentu menarik untuk dikaji lebih dalam.

Terkait dengan hal tersebut, penelitian tentang budaya yang dikaji secara tradisi pernah dilakukan oleh Munawirsazali, (2019). Dia mengkaji tentang produk lokal sekenam dan sekepat di Lombok Tengah. Dalam tradisi 
tersebut, setiap rumah memiliki sekenem dan sekepat untuk melindungi para perempuan. Sekenem dan sekepat berbentuk gazebo, sebuah tempat berukuran $2 \times 6$ meter (sekenem) dan $2 \times 2$ meter (sekepat). Secara khusus, tempat ini dibuat khusus oleh pemilik rumah yang memiliki anak perempuan. Tempat ini berfungsi sebagai tempat pertemuan para perempuan yang didatangi oleh tamu-tamunya, terutama laki-laki. Meski demikian, di tempat ini mereka duduk berjauhan guna melindungi sang perempuan. Namun dalam perkembangan globalisasi, sekenem dan sekepat sebagian telah difungsikan sebagai pertemuan laki-laki dan perempuan tanpa mematuhi norma-norma budaya setempat. Arus informasi dan globalisasi yang datang secara masif dan cepat membuat banyak budaya lokal tereduksi. Inilah yang membuat nilai-nilai kearifan lokal menjadi tergerus.

Demikian halnya dengan penelitian saat ini. Di tengah arus informasi dan globalisasi, nilai-nilai yang ditanamkan dalam produk budaya lokal semakin lama semakin tereduksi. Informasi yang sangat mudah diakses memudahkan budaya-budaya lain melakukan penetrasi, khususnya budaya Barat.

\section{METODE PENELITIAN}

Jenis penelitian ini adalah kualitatif dengan menggunakan paradigma kritis. Sebuah paradigma yang menilai realitas sosial bukan sebagai sebuah realitas yang netral, melainkan sengaja dibentuk oleh dan untuk kepentingan politik, ekonomi, dan sosial yang dikuasai oleh kelompok-kelompok yang dominan dalam masyarakat.(Baxter, Leslie A. \& Babbie, 2018) Dalam hal ini menilai realitas kesenian tradisional Reog Ponorogo yang dibentuk atas dasar kepentingan tertentu, khususnya pasar.

Tujuan penelitian kualitatif dalam kasus ini adalah untuk memahami makna simbol-simbol Reog Ponorogo dengan menggunakan ajaran asthabrata dan kosmogoni Jawa : keblat papat kelimo pancer. Peneliti melakukan wawancara mendalam kepada narasumber (informan). Pendekatan kualitatif dideskripsikan sebagai penelitian yang induktif dan ideografik. Induktif berarti dipakai untuk menggali dan menjelaskan temuan-temuan yang khusus didalam situasi yang bersifat umum tanpa bertujuan menerima atau menolak hipotesa. Sedangkan ideografik menempatkan temuan ke dalam konteks waktu dan sejarah yang spesifik sehingga kebenaran yang ditemukan dalam penelitian kualitatif bukanlah kebenaran satu-satunya dalam konteks sejarah dan waktu tertentu (Neuman, 2011:76)

Metode yang digunakan dalam penelitian ini adalah observasi dan wawancara mendalam. Informan yang dipilih adalah tokoh bidang kajian budaya Jawa, Prof. Dr. Dharsono. Sedangkan unit analisis dalam penelitian ini adalah simbol-simbol yang melekat dalam elemen-elemen dalam pementasan Reog Ponorogo.

\section{HASIL DAN PEMBAHASAN}

Dalam pandangan budaya Jawa ada tiga macam jagad dalam sisi kehidupan yaitu hubungan antara jagat atas (alam niskala), jagat tengah (alam niskala-sakala), dan jagat bawah (alam sakala). Ketiga jagad ini harus diupayakan secara terus menerus untuk menyelaraskan hubungan secara kosmis yaitu untuk menjaga keseimbangan secara horizontal dan vertikal. Secara horizontal menjaga keseimbangan antara dirinya dengan alam semesta dan secara vertikal menjaga keseimbangan terhadap ke-esaan (hubungan mikrokosmos dan makrokosmos) (Dharsono, 2007:34).

Sementara dalam tata alam atau dunia (kosmologi) Jawa dikenal dengan mikromakro-metakosmos. Mikrokosmos merupakan manusia secara esensi. Sebaliknya, makrokosmos adalah manusia secara eksistensi (alam semesta). Sedangkan metakosmos terdiri dari alam niskala yang tak terindera. Dalam bentuk ritual dikenal dengan konsep mandala yaitu sebuah interaksi kosmos yang membentuk satu kesatuan dan keseimbangan.

Mandala digambarkan sebagai sebuah totalitas unsur-unsur dualitas keberadaan dunia atas dan dunia bawah yang menyatu melalui dunia tengah. Apabila konsep tiga jagad dan mandala digabungkan, maka akan terbentuk sebuah lingkaran yang melambangkan kesempurnaan, keutuhan, keutuhan, kelengkapan, tanpa cacat, dan kegenapan semesta yang bersifat esensi, sebuah energi 
yang sangat besar namun tak tak terindera. (Sumardjo, 2003:87).

\section{Ajaran Asthabrata}

Menurut Edi Sedyawati (dalam Dharsono, 2006), asthabrata menyimbolkan alam semesta. Secara harfiah yaitu delapan simbol alam. Namun sejatinya, asthabrata menyiratkan sebuah keharmonisan sistem alam semesta. Kedelapan sifat tersebut merupakan manifestasi dari keselarasan tata alam semesta yang diciptakan Tuhan. Artinya, jika ingin selamat dan terhindari dari malapetaka, maka manusia harus menyelaraskan diri dengan tata alam semesta.

Delapan simbol alam asthabrata tersebut antara lain serngenge, bulan, lintang, langit, angin, banyu, geni, dan bumi. Delapan simbol ini dijadikan sebagai tingkah laku seorang raja. Ajaran asthabrata menjelaskan delapan simbol-simbol itu sebagai berikut. Pertama, serngenge. Matahari yang memancarkan sinar terang. Matahari adalah simbol sumber kehidupan semua makhluk. Seorang pemimpin harus mampu menumbuhkembangkan rakyatnya agar bersama-sama mampu membangun sebuah bangsa dan negara secara lahir dan batin. Kedua, bulan yang memancarkan sinar di tengah kegelapan pada malam hari. Bulan memiliki cahaya yang lembut sehinga mampu menumbuhkan semangat dan masa depan yang gemilang. Seorang pemimpin harus mampu memberikan semangat dan mendorong rakyatnya agar selalu bangkit, baik dalam keadaan suka maupun duka. Ketiga, lintang. Bintang yang memancarkan sinar indah berkilauan. Bintang memiliki tempat di langit sehingga bisa menjadi pedoman arah. Seorang pemimin harus menjadi panutan atau teladan bagi rakyatnya. Seorang pemimpin juga tidak boleh ragu dengan keputusan-keputusannya yang sudah disepakati, serta tidak boleh terpengaruh dengan siapapun yang berniat jahat. Keempat, langit yang luas dan tak terbatas. Langit mampu menampung apapun yang di dunia. Seorang pemimpin harus memiliki keluasan hati dan mampu mengendalikan diri dengan baik, kuat, dan sabar. Karena itu seorang pemimpin harus mampu menampung berbagai macam pendapat rakyatnya. Kelima, angin yang selalu ada di mana-mana, baik dalam ruang maupun tanpa ruang. Seorang pemimpin harus selalu dekat dengan rakyatnya, tanpa membedakan kelas dan derajatnya. Seorang pemimpin juga harus mampu mengetahui keinginan serta memahami dan menyerap aspirasi rakyatnya. Keenam, banyu. Air atau laut yang memiliki permukaan yang rata dan sejuk. Seorang pemimpin harus adil, tanpa membedakan derajat dan martabat rakyatnya. Dia harus memiliki kasih sayang pada rakyatnya. Ketujuh, geni. Api yang memiliki sifat menghancurkan sesuatu. Api mampu membakar dan menghabiskan segala sesuatu yang menyentuhnya. Seorang pemimpin harus tegas dan berwibawa. Dia harus mampu menegakkan kebenaran dan keadilan secara tegas dan tuntas tanpa memandang siapapun. Kedelapan, bumi yang memiliki karakter kuat dan murah hati. Bumi memiliki sifat memberi pada siapapun yang mengolah dan memeliharanya dengan rajin dan konsisten. Seorang pemimpin harus memiliki sifat yang teguh, sentosa, murah hati, sukaberderma, dan selalu berusaha tidak membuat rakyat kecewa.

Sejalan dengan apa yang dikatakan oleh Sudirga (dalam Sumiati \& Girsang, 2018) bahwa kesenian membawa manusia kepada kehidupan spiritual menuju kedamaian dan kesejahteraan melalui kesenian. Artinya dengan kesenaian, manusia dapat mencapai kehidupan spiritual yang penuh kedamaian dan kesejahteraan dalam kehidupan.

\section{Ajaran Kosmogoni Jawa: Keblat Papat Kelimo Pancer}

Pandangan masyarakat Jawa dalam menjaga keseimbangan, baik vertikal maupun horisontal, menurut Rachmat Subagyo (dalam Dharsono, 2007:34), dikenal dengan keblat papat kelimo pancer atau dunia waktu. Keblat papat kelimo pancer memiliki pola empat mata angin dengan satu pusat. Artinya, satu-kesatuan terjadi justru karena adanya perbedaan. Hal ini merupakan dasar dari kekuatan untuk mencapai satu keseimbangan dan keselarasan hidup dengan cara melakukan pengendalian diri.

Secara rinci, pandangan keblat papat kelimo pancer dalam kosmogoni Jawa terbagi dalam lima karakter yaitu pertama, bumi (tanah). Elemen berwarna hitam menuju arah utara ini melambangkan nafsu lawwamah yaitu serakah, lapar, dahaga, dan kantuk. Kedua, api. Elemen berwarna merah menuju arah selatan 
ini melambangkan nafsu ammarah yaitu angkara murka, iri, garang, dan pemarah. Ketiga, angin. Elemen angin berwarna kuning yang menuju arah barat. Elemen ini melambangkan nafsu sufiah yaitu nafsu birahi, membangkitkan hasrat, kesenangan, dan rindu. Keempat, air. Elemen berwarna putih menuju arah timur ini memiliki sifat mutmainnah yaitu jujur, tentram, dan baik. Kelima, pusat bumi. Elemen ini berwarna hijau dengan posisi tengah. Bumi melambangkan kama yaitu budi yang menggambarkan nafsu batin manusia (Simuh dalam Dharsono, 2006).

Manusia memiliki kelima sifat tersebut sehingga untuk menjaga keseimbangan dan pengendalian diri, tergantung masing-masing individu. Demikian halnya dengan kesenian Reog Ponorogo, unsur-unsur kehidupan (makrokosmos) di dunia menempel pada simbol-simbol Reog Ponorogo. Semua sifatsifat tersebut pada hakikatnya berada dalam diri manusia (mikrokosmos). Dalam religi Jawa, sifat-sifat pengendalian diri ini disebut dengan Nur-Rasa/Nur-Cahyo : dasar kehendak yaitu menggerakkan kehendak jiwa (cipta rasa) dan kehendak budaya (cipta karsa) (Kartosoejona dalam Dharsono, 2006) .

\section{SIMBOL-SIMBOL REOG PONOROGO.}

\section{Kelana Sewandono}
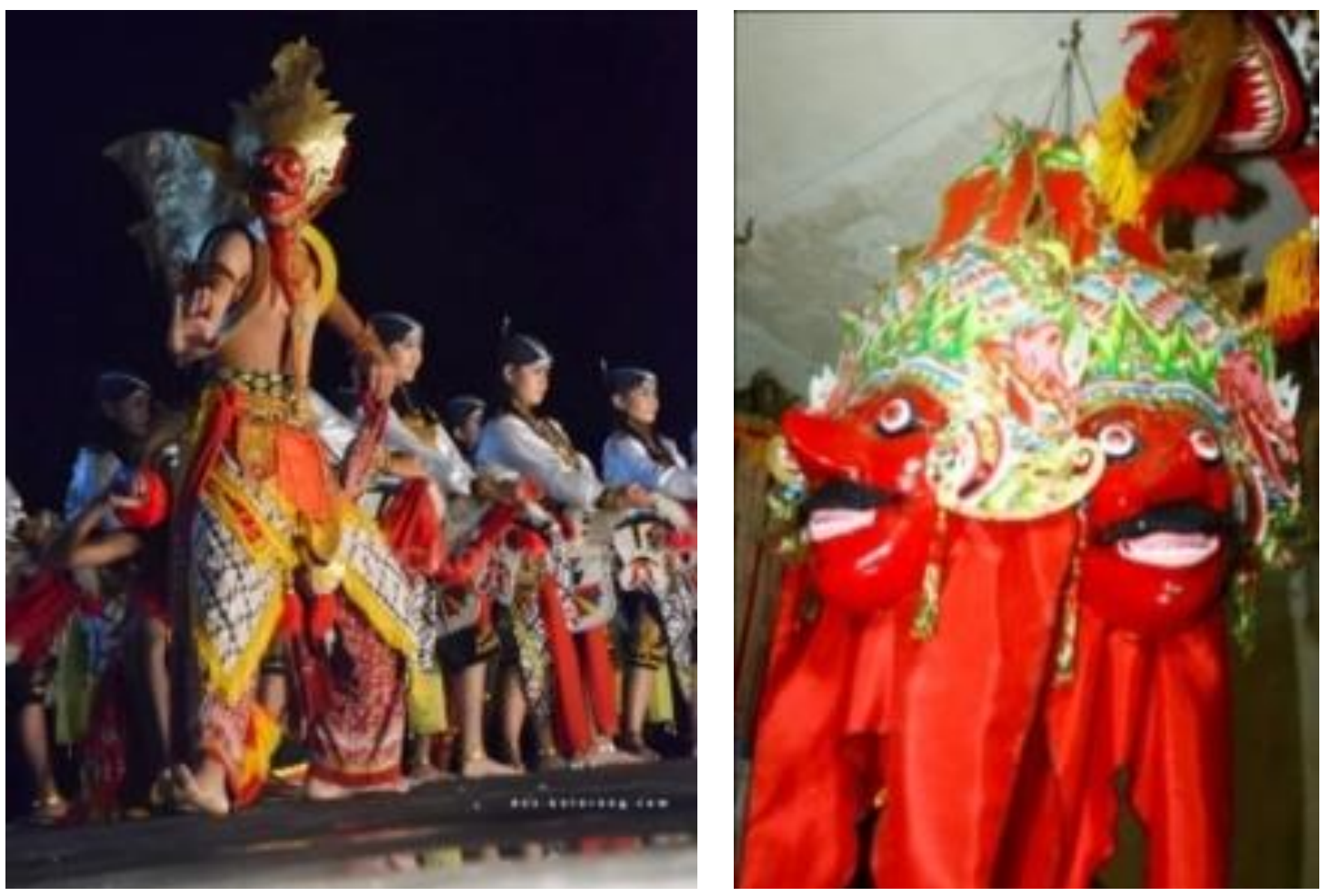

Gambar 1. Karakter Kelana Sewandono

Sumber: http://aryoghi26.blogspot.com, dokumentasi peneliti

Kelana Sewandana yang digambarkan sebagai sosok raja. Perwakannya gagah. Simbol Kelana Sewandana dimaknai sebagai seorang pahlawan yang menyelamatkan atau membesarkan Ponorogo. Tokoh ini menjadi teladan bagi masyarakat.

Topeng yang digunakan karakter Kelana Sewandono yaitu warna muka merah, mahkota raja, bentuk mulut delimo mletek, bentuk mata dondongan, bentuk alis kuwel. Topeng ini memiliki makna keberanian, kebijaksanaan, dan kewibawaan. Karakter tokoh ini digambarkan sebagai tokoh penyelamat atau pahlawan.

Pakaian Raja Kelana Sewandono dominan warna merah dan kuning emas. Warna 
ini memberikan makna kewibawaan dan

kebijaksaan yang dimiliki oleh seorang raja.

\section{Cambuk Samandiman}

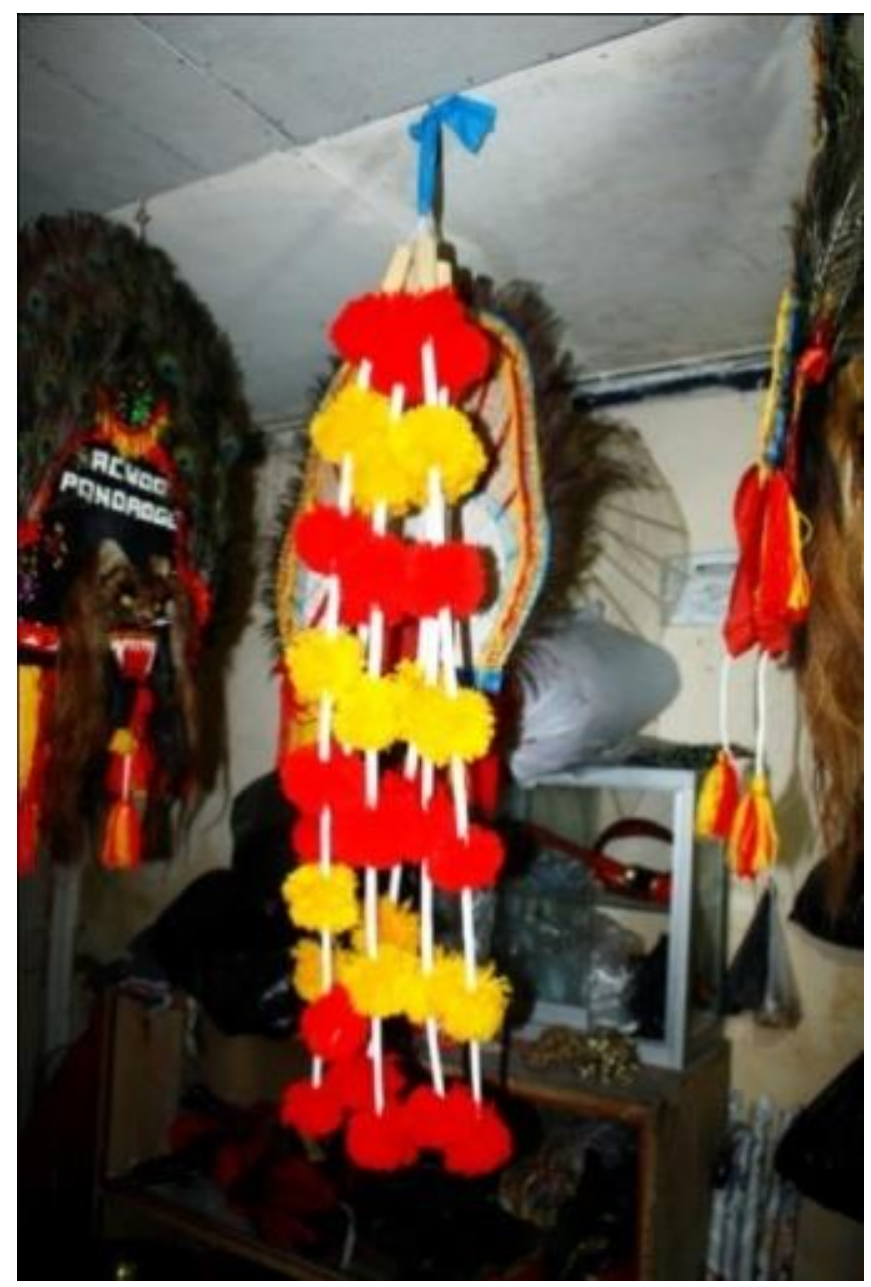

Gambar 2. Cambuk Samandiman

Sumber:dokumentasi peneliti

Cemeti atau cambuk ini merupakan senjata andalan yang digunakan oleh raja Kelana Sewandhana. Cambuk ini digunakan unuk bertarung melawan singo Barong ketika bertemu didalam hutan, cambuk merupakan senjata yang sangat sakti mandraguna, sehingga membuat raja penguasa hutan yaitu SingobBarong bertekuk lutut. Cambuk Samandiman adalah cambuk yang digunakan oleh raja Kelana Sewandhana. Cambuk ini memiliki hiasan yang menyerupai bulatanbulatan kecil yang memiliki warna warna kuning dan merah yang terbuat dari beberapa helai benang wol yang dijadikan satu. Hiasan tersebut berjumlah tujuh buah. Angka tujuh dimaknai sebagai indera manusia yang senantiasa dijaga sehingga mendapatkan sebuah berkah dari Sang Kuasa. Artinya, seorang pemimpin harus memiliki sebuah "pegangan" atau senjata pamungkas. 


\section{Tokoh Bujang Ganong}
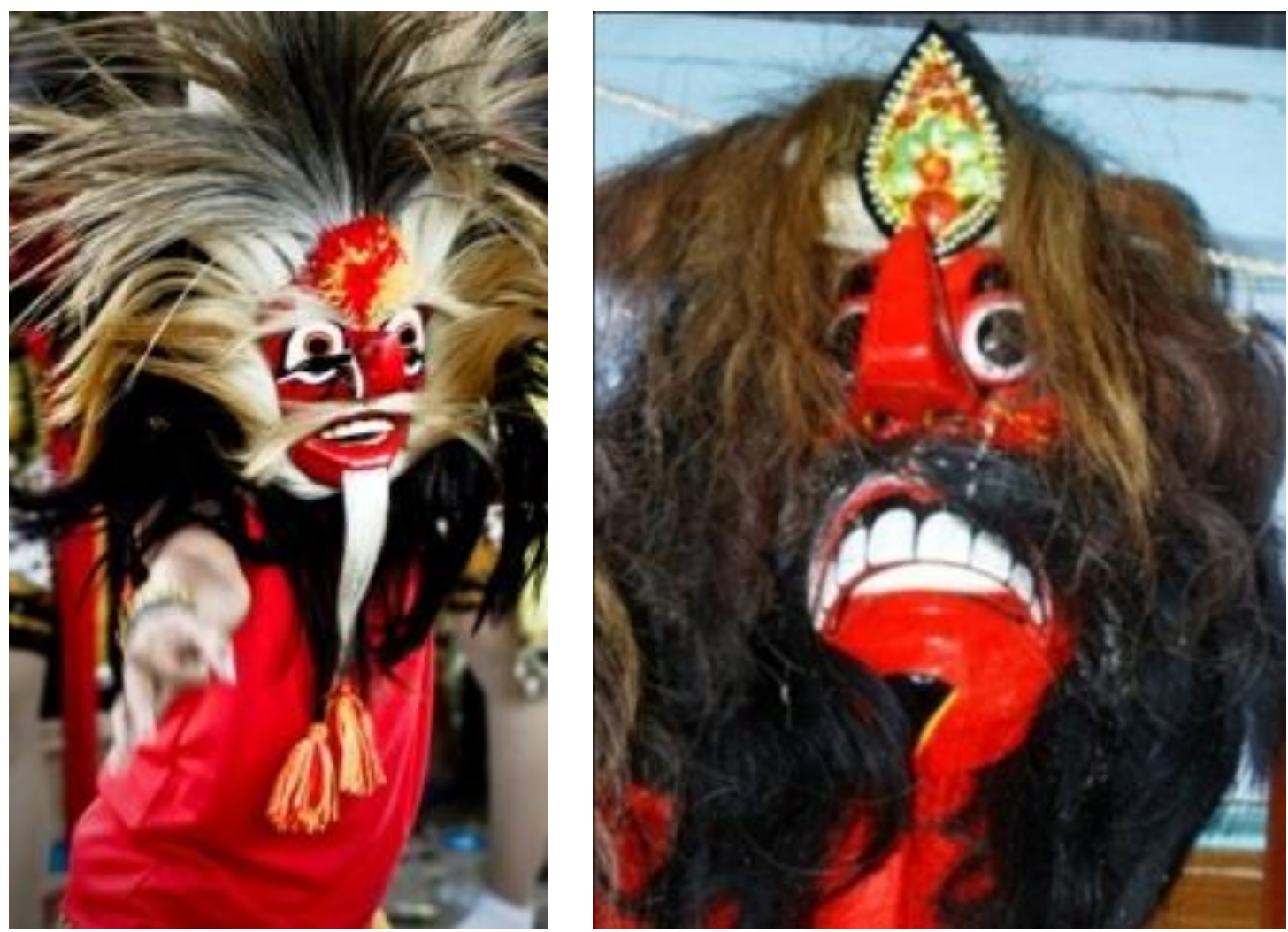

Gambar 3. Tokoh Bujang Ganong

Sumber: https://nabilahwitsqa.wordpress.com, dokumentasi peneliti

Bujang Ganong merupakan salah satu tokoh dalam pagelaran Reog yang ditunggu kemunculannya oleh masyarakat yang menyaksikan. Tokoh ini meskipun tampak jenaka tapi memiliki kesaktian yang luar biasa. Hal ini menimbulkan sebuah mitos di masyarakat mengenai sifat-sifat manusia. Berdasarkan cerita versi bantarangin, Bujang Ganong atau Patih Pujanggo Anom adalah patih dari Raja Kenana Sewandana yang diutus untuk melamar Dyah Ayu Dewi Songgolangit yang merupakan putri kerajaan kediri.

Topeng Bujang Ganong memiliki warna muka merah dengan bentuk mulut

Singo Barong, bentuk mata Dondongan, dan bentuk rambut gimbal warna kuning kecoklatan. Topeng ini terbuat dari kayu, rambutnya terbuat dari bulu ekor sapi atau kuda. Tutup kepalanya terbuat dari kain polos warna merah. Pada ujung kiri dan kanannya diberi tali agar dapat diikatkan pada leher pemainnya. Tinggi topeng 21 centimeter dengan lebar 20 centimeter, panjang topeng 7 centimeter dan tebal 10 centimeter. Maknanya adalah keberanian dan keceriaan. Tokoh ini sebagai pendamping dan penjaga sekaligus sebagai tokoh jenaka dalam pagelaran. Tokoh Bujang Ganong menggambarkan sosok patih muda yang cekatan, cerdik, jenaka, dan sakti.

Celana yang digunakan Bujang Ganong adalah celana dingkikan berwarna hitam berserat putih yang terletak di samping dan bawah. Dingkikan artinya sepanjang pertengahan betis dengan model kolor. Topeng Bujang Ganong menggunakan Binggel atau gelang kaki yang berwarna emas, sama dengan yang digunakan oleh penari Jathilan. Sedangkan embong gombyok yang berfungsi sebagai penutup bagian celana ini terbuat dari kain warna dasar hitam. Gombyok terbuat dari benang sayet atau benang songket berwarna kuning dan merah. Pakaian Bujang Ganong berwarna merah berserat hitam pada leher, 
lengan, serta lengkung rompi yang terbuat dari kain berwarna dasar merah polos.

\section{Tokoh Jathilan}

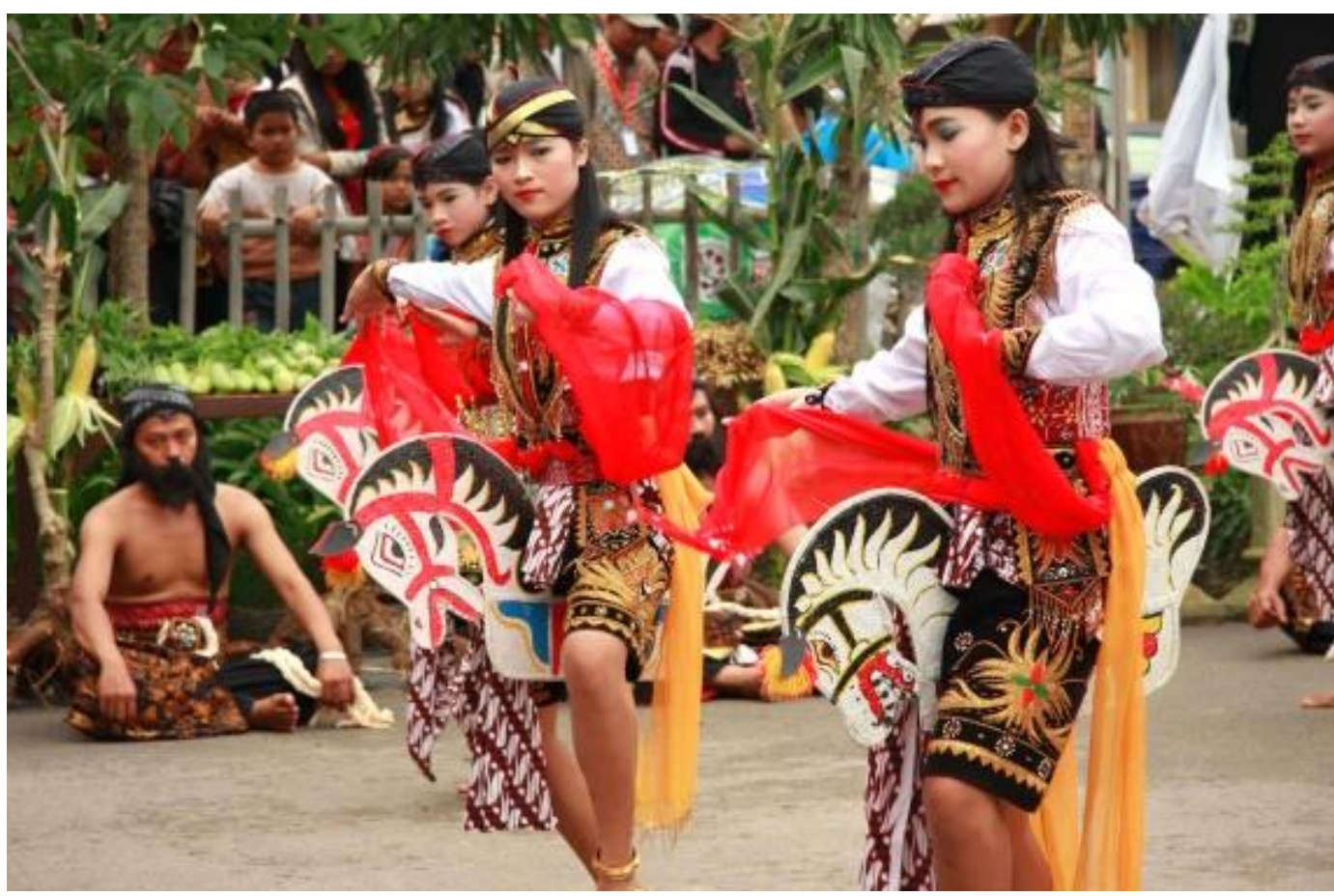

Gambar 4. Tokoh Jathilan

Sumber: https://khabarjoss.wordpress.com//

Jathilan disebut juga sebagai penari kuda kepang. Biasanya mereka masuk ke dalam panggung setelah penampilan dari para Warok muda yang telah berlatih dan diawasi oleh Warok tua. Gerak tari Jathilan terkesan lembut dan kompak yang mengikuti irama dari gamelan. Pada awalnya penari Jathilan ini dilakukan oleh seorang pemuda dengan gaya lemah lembut layaknya seperti seorang wanita. Namun saat ini tokoh Jathilan ditampilkan dengan sosok yang heroik sesuai dengan jalan ceritanya yaitu menggambarkan beberapa prajurit yang sedang melakukan latihan berperang meskipun pelakunya wanita, hal ini dilakukan demi tidak kehilangan nilai keindahan pada tarian tersebut.

Jathilan menggunakan pakaian layaknya seorang prajurit dengan menunggangi kuda berwarna merah, kuning, hitam dan putih. Jathilan menggunakan celana dingkikan kepanjen yaitu celana sepanjang bawah lutut terbuat dari kain beludru warna hitam yang dibordir dengan monte warna kuning emas, tepat selutut sampai paha. Kain panjang yang digunakan Jathilan berjenis parang barong. Kain ini lebih kecil dari yang digunakan oleh karakter Klana Sewandana. Sebelum dipakai, kain ini di-wiru atau dihias lipat seleber tiga jari dengan ukuran setengah panjang kain. Pinggiran kain yang berwarna putih polos tidak kelihatan atau dimasukkan. Sementara Barabara Samir terbuat dari kain beludru dengan warna hitam dihiasi dengan bordir monte dengan warna kuning emas. Bara-bara diletakkan di sebelah kanan, sedangkan Samir (yang terbelah) diletakkan di sebelah kiri.

Sebagai tunggangannya, Jathilan menggunakan eblek atau jaranan. Menurut ajaran cupu manik astagina yang diajarkan oleh Sunan Kalijaga, salah satu dari delapan ajaran yang mengarah pada "hidup sejahtera" adalah turangga, berarti manusia harus memiliki kuda tunggangan. Eblek atau jaranan didominasi warna putih. Warna utih atau watak samudra 
adalah laut atau air, diteladani oleh Bhatara Baruna. Laut, betapapun luasnya, senantiasa mempunyai permukaan yang rata dan bersifat sejuk menyegarkan.

\section{Tokoh Warok}
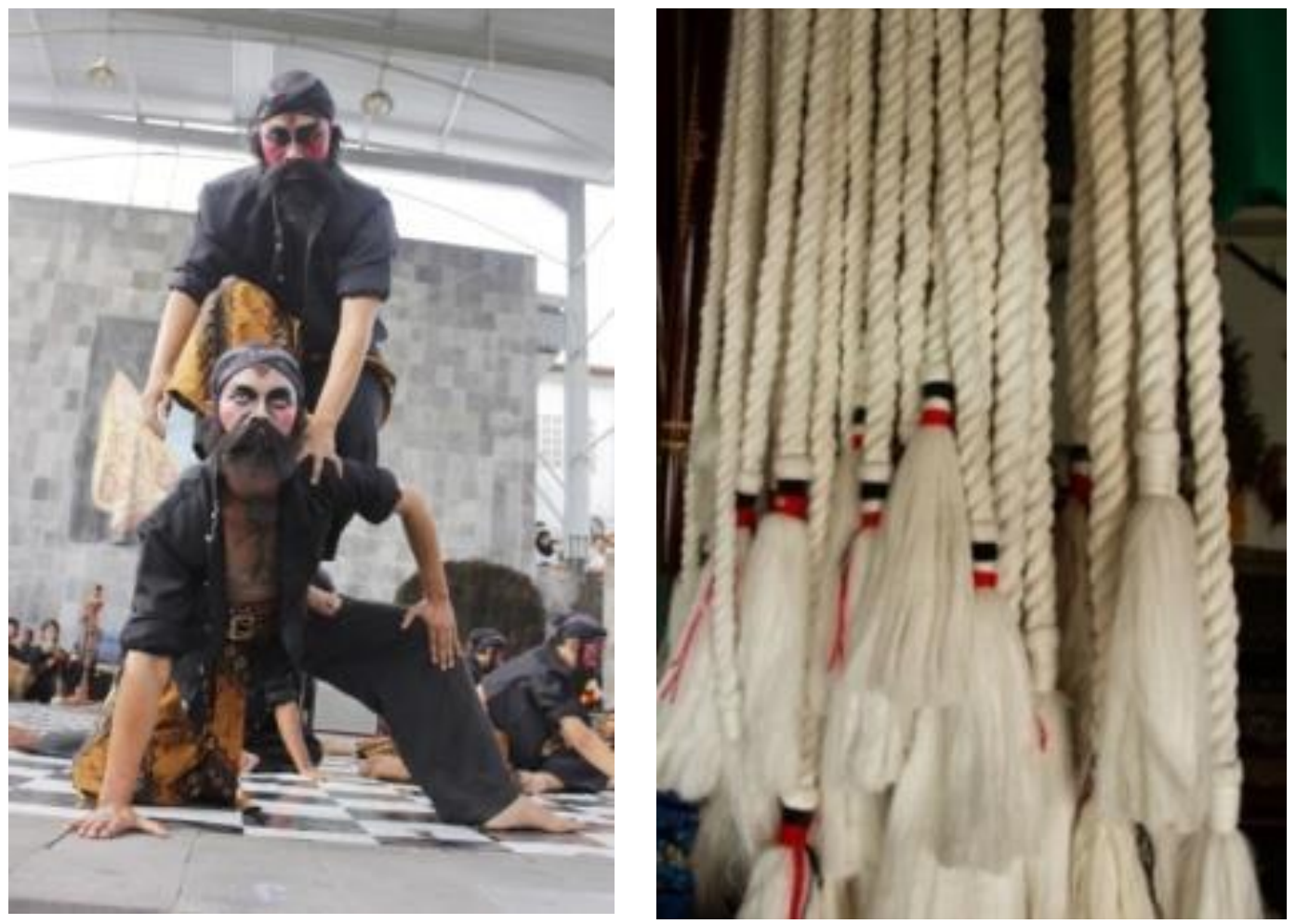

Gambar 5. Tokoh Warok

Sumber: http://kerajaan-jaseters.blogspot.com, dokumentasi peneliti

Dalam pertunjukannya, Warok diperankan oleh pria yang gagah yang berlatih ilmu kanuragan dengan Warok lainnya. Gerakan tari dari Warok terkesan berat dan kaku. Dalam penampilannya, Warok terdiri dari empat orang atau lebih dan biasanya saling berpasangan.

Warok berpakaian serba hitam dengan hiasan kolor atau biasa disebut sabuk kolor berwarna putih. Kolor usus ini merupakan senjata sakti dari Warok. Dalam pengertian ini sebenarnya kolor usus digunakan untuk mengikat pakaian yang serba hitam. Artinya kolor ini digunakan untuk menekan hawa nafsu dari manusia.

Warok, secara harfiah berasal dari kata wewarah yaitu tekat suci. Seorang Warok digambarkan sebagai orang yang memberikan tuntunan dan perlindungan tanpa pamrih.
Dalam filosofi Jawa, Warok digambarkan sebagai orang yang telah sempurna dalam laku kehidupannya. Keberadaan karakter Warok merupakan representasi masyarakat Ponorogo melihat sosok yang menjadi panutan bagi mereka. Seorang Warok direpresentasikan sebagai tokoh yang memiliki kelebihankelebihan khususnya dibandingkan dengan manusia biasa, Warok dipercaya memiliki ilmu kanuragan (kekebalan tubuh) dan memiliki drajat spiritual yang tinggi. Tokoh Warok harus memiliki sifat Kesatria, jujur, gemar menolong, lemah-lembut, mampu menggabungkan dua karakter yang bersebarangan dalam dirinya sekaligus, tegas, santun, keras, berwibawa, dan dapat menjaga emosi dalam dirinya dengan baik, serta memiliki kesaktian dan ilmu kanuragan. Persyaratan yang ketat untuk menjadi seorang Warok, sehingga Warok ini 
menjadi tokoh yang disegani dimasyarakat, meskipun jumlah Warok tidak banyak pada saat ini.

\section{Dhadak Merak dan Singo Barong}
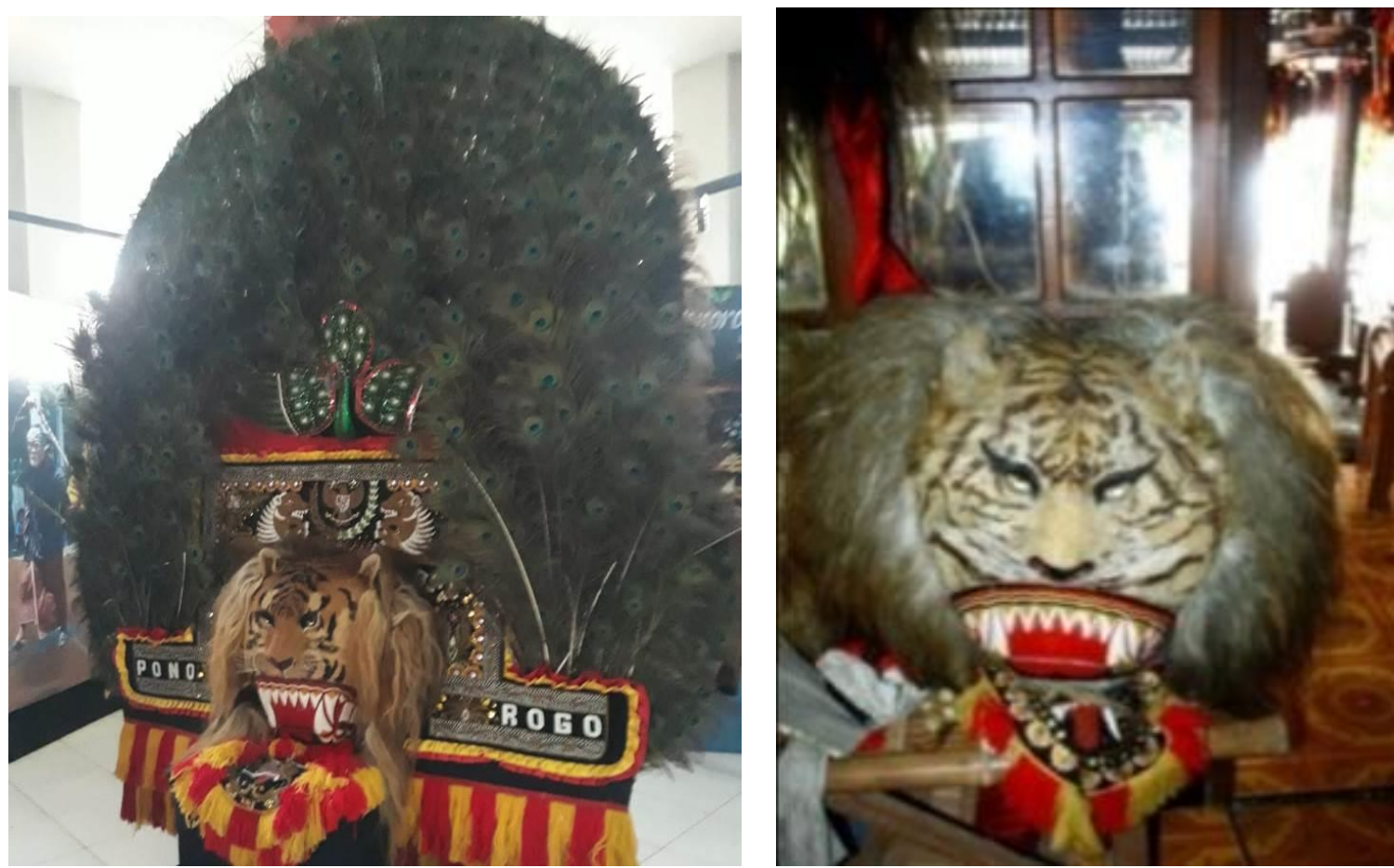

\section{Gambar 6. Dhadak Merak \\ Sumber: dokumentasi peneliti}

Dhadak Merak adalah elemen utama dalam pagelaran Reog ponorogo. Elemen ini terdiri dari kepala harimau yang terbuat dari kayu dadap, bambu, dan rotan yang dilapisi oleh kulit harimau. Dhadak Merak digunakan sebagai tempat menata bulu merak. Dhadak Merak ini tampak kelihatan indah ketika mengembangkan bulu-bulunya dan saat menggigit tasbih (sarana dizikir atau pengingat kepada Tuhan).

Sedangkan krakab dibuat dari kain berbahan beludru dengan warna hitam dan disulam dengan monte-monte. Krakab digunakan sebagai penghias dan dijadikan sebagai media identitas dari sebuah grup Reog. Sementara kerudung sebagai penutup pembarong terbuat dari sebuah kain yang berwarna hitam dan dihiasi kain berwarna merah melintang.

Warna yang terdapat pada karakter Dhadak Merak adalah dominan warna merah, kuning, hitam, putih dan hijau. Sedangkan warna mukanya adalah warna kuning dan hijau. Mahkota Dhadak Merak terdiri dari bulu burung merak dan kepala harimau. Bentuk mulutnya Singo Barong. Sedangkan bentuk rambutnya seperti rambut pada singa. Sementara bentuk matanya seperti mata harimau.

Makna yang terkandung dari Dhahak Merak dengan perpaduan bulu burung merak yang indah adalah kekuatan, keindahan, kekuasaan, dan keberanian, tokoh ini sebagai sentral cerita dan tokoh utama. Dari kedua binatang yang kontras dan diwujudkan dalam sebuah topeng karya seni yang bermakna tentang kehidupan bersama dan damai. Harapannya adalah masyarakat ponorogo memiliki karakter yang sopan, berani, berwibawa, dan selalu membawa kedamaian.

Sedangkan Singo Barong berbentuk kepala harimau, berbadan manusia, di atasnya dihinggapi burung merak. Jika barongan dan 
Dhadak Merak disatukan maka memiliki bera sekitar 40-60kg.

Berdasarkan ajaran Triloka, karakter ini mengandung makna atau pengertian yaitu burung merak berarti Alam Niskala /svarloka (dunia para dewa), kepala harimau Alam Sakala Niskala/bhuvarloka (dunia orang-orang yang tersucikan). Sedangkan orang yang membawa topeng ini adalah Alam Sakala/Bhurloka (dunia manusia). Pengertiannya adalah sebagai manusia bila ingin mencapai kesempurnaan hidup harus melalui berbagai macam cobaan.

\section{Reog dan Selera Pasar}

Penelitian tentang nilai-nilai filosofi budaya dari sebuah seni pertunjukan tradisional pernah dilakukan oleh (Arisyanto et al., 2019), yaitu tentang pertunjukan Barongan Kusumojoyo. Penelitian tersebut melihat seni Barongan tidak lagi mengutamakan nilai filosofi tetapi pada kebutuhan estetis yang hubungan dengan selera pasar. Sekalipun nilainilai budaya masih melekat pada warna-warna pada barongan yaitu merah, kuning, hitam, dan putih yang merupakan simbol nafsu manusia.
Namun kelompok-kelompok tari yang menjadi bagian dari barongan seperti tari jaranan, ayam, buto, dan bendera, semua mengikuti selera pasar. Sekalipun penelitian Prasena dkk sama dengan penelitian ini yang melihat pereduksian nilai-nilai budaya tradisional karena selera pasar, tapi penelitian ini lebih banyak mendiskripsikan nilai-nilai tradisi Jawa yang terdapat dalam simbol.

Rendahnya kajian tentang makna di balik simbol-simbol Reog untuk kepentingan wisata berimplikasi pada hilangnya nilai-nilai budaya pada kesenian Reog. Program city branding yang digagas pemerintah setempat yang tidak disertai kajian mendalam, membuat Reog tidak lagi menjadi kekuatan budaya yang menyimpan nilai-nilai adiluhung. Seni Reog telah menjelma menjadi patung, gapura, dan visual-visual lain yang dipajang banyak tempat. Banyaknya media tidak saja mereduksi nilainilai yang terkandung dalam simbol Reog tetapi juga menghilangkan unsur magis di dalamnya.

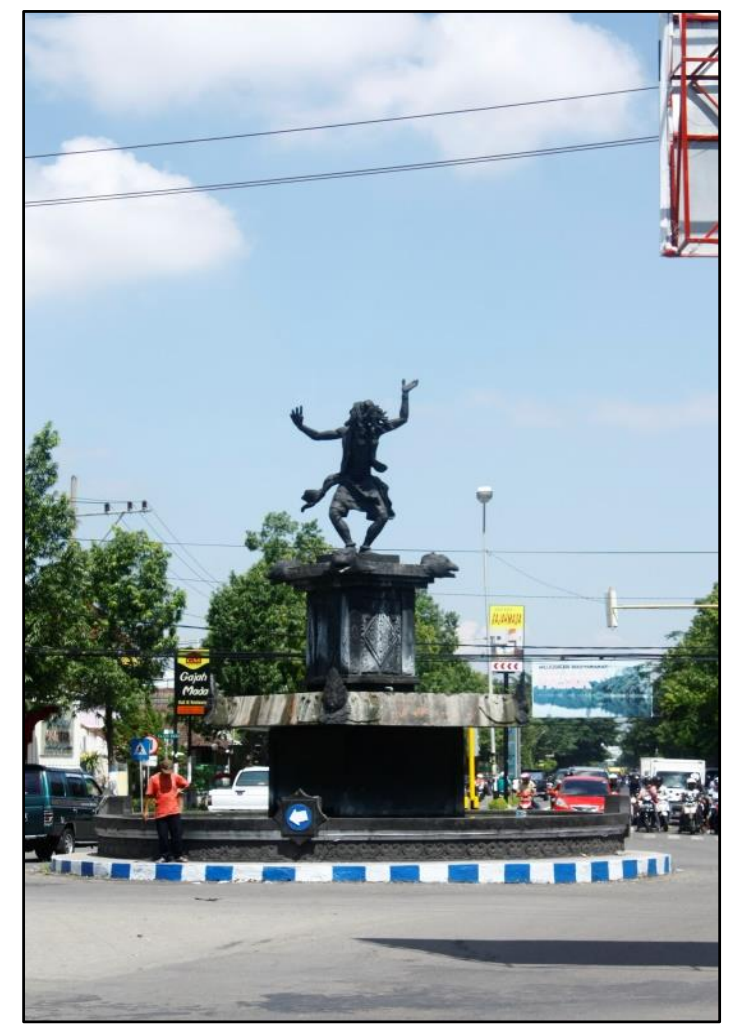

Gambar 7: Patung Reog di Perempatan Kota Ponorogo Sumber: Dokumentasi Peneliti 
Demikian juga dengan pertunjukanpertunjukan Reog yang banyak dilakukan di tempat-tempat publik dengan tidak menyertakan pakem-pakem tradisi Reog semakin mereduksi nilai-nilai budaya dalam Reog.

Adorno mengkritik budaya modern ini dengan menawarkan konsep komodifikasi, standardisasi, massifikasi, dan pengulangan terhadap produk-produk budaya untuk memenuhi kebutuhan massa atau pasar (Bahruddin, Muh, Yurisma, 2017). "Inilah rahasia sejati keberhasilan," demikian kata Adorno. Menurutnya, asas pertukaran telah memaksakan kekuatannya secara khusus pada artefak atau benda-benda budaya (Adorno dalam Strinati, 2007:63).

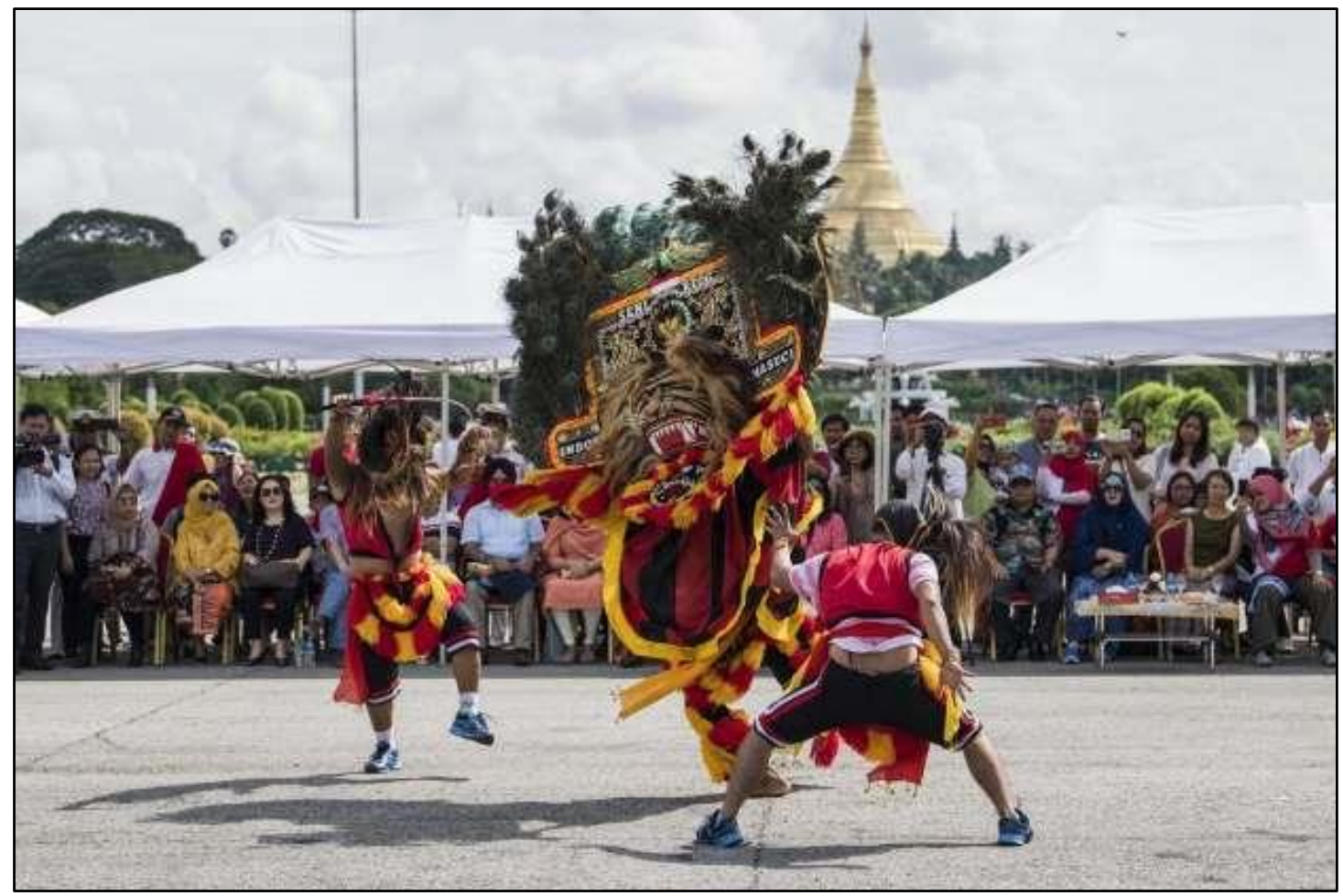

\section{Gambar 8: Pertunjukan Reog Sumber: www.msn.com}

Reog bukan lagi sebuah seni budaya yang memerlukan ritual khusus dalam setiap pertunjukan melainkan dikomodifikasi menjadi sebuah barang dagangan yang dikomersialkan. Pada tahapan ini, produk Reog disesuaikan dengan permintaan pasar dengan standarstandar pasar pula. Produk-produk yang berkaitan dengan Reog kemudian diproduksi secara massal bahkan dibuat replika-replika yang menyerupai Reog. Jika selama ini kekuatan magis melekat pada Reog, maka sejak diproduksi secara massal dan dibuat replikareplika dan elemen-elemen penting Reog direduksi, kekuatan magis menjadi pudar. Reog hanya tampak di permukaan saja tanpa ada kekuatan atau ruh lagi di dalamnya.

Industri kreatif atau industri budaya yang disebut-sebut sebagai tren abad 21, dianggap mampu menjadi kunci revitalisasi ekonomi, kemakmuran dan kesejateraan, pembangunan lokal, hingga regenerasi kota. Bahkan, dengan digalakkannya industri kreatif oleh pemerintah, sektor-sektor lain diprediksi mampu menggerakkan roda ekonomi seperti bisnis kuliner, makanan,

pakaian, akomodasi, transportasi, dan lain sebagainya. Namun justru di sinilah konsep industri kreatif menjadi bias. Semua sektor mengklaim sebagai bisnis kreatif sehingga 
masyarakat gagal mengidentifikasi industri kreatif. Bahkan sebagian dari mereka berubah menjadi bisnis spekulatif (Lin, Li-Min, TainDow, 2014).

Green (dalam Adekola, G and Egbo, 2016) menekankan bahwa sejumlah tradisi memang sengaja diciptakan untuk alasan tertentu. Di sisi lain, tradisi juga dapat disesuaikan dengan kondisi masyarakat sehingga perubahan-perubahan yang terjadi bisa diterima sebagai bagian tradisi lama. Hampir setiap generasi berpotensi untuk mengubah tradisi sehingga bukan dianggap sebagai sesuatu yang penting. Oleh karena itu, masyarakat secara tidak sadar bahwa tradisi selalu mengalami perubahan sehingga menjadi besar selama beberapa generasi. Namun, masyarakat tidak menganggap bahwa tradisi lama telah berubah dengan signifikan.

\section{SIMPULAN}

Simbol-simbol dalam Reog Ponorogo memiliki makna terkait dengan nafsu yang ada dalam diri manusia. Simbolisasi dalam kesenian Reog membentuk makna-makna dan nilai-nilai adiluhung di masyarakat. secara umum, Reog Ponorogo merupakan sebuah pertunjukan yang bisa memberikan tuntunan dalam menjalani kehidupan bagi yang melihatnya atau mengerti secara mendalam.

Reog kaya akan makna dan nilai yang ditanamkan oleh para penciptanya sehingga menjadi sebuah peninggalan budaya yang ada saat itu. Namun dalam banyak pertunjukan, seperti festival tahunan Reog Ponorogo dalam rangka memperingati Tahun Baru Hijriyah atau Tahun Baru Islam (masyarakat menyebut sebagai Grebeg Suro), Reog Ponorogo kerap mengalami reduksi nilai-nilai yang seharusnya ada dalam pertunjukan.

Caturwati, (2007:169) melihat pereduksian seni dan budaya di Indonesia dimulai sejak tahun 1990-an. Seni dan budaya Indonesia telah mengalami perubahan orientasi di berbagai bidang seperti ekonomi, politik, dan sosial. Perubahan ini terjadi karena kesenian dipahami sebagai kebuah kegiatan bisnis. Karena itu, banyak masyarakat yang memanfaatkan produk kesenian sebagai sebuah barang dagangan. Sebagai sebuah komoditas, kesenian Reog kerap 'dijual' murah-meriah dalam setiap pertunjukan. Hal ini berimplikasi pada simbol-simbol dan ritual-ritual yang direduksi sehingga menghilangkan nilai-nilai budaya maupun kekuatan magis yang selama ini menjadi ciri khas dan kekuatan Reog Ponorogo.

\section{DAFTAR PUSTAKA}

Adekola, G and Egbo, N. C. (2016). Traditions and Customs in Community Development: The Case of Nkanu West and Nkanu East Local Government Areas of Enugu. Journal of Education and Practice, 7(18), 120-127.

Arisyanto, P., Untari, M. F. A., \& Sundari, R. S. (2019). Struktur Pertunjukan dan Interaksi Simbolik Barongan Kusumojoyo di Demak. Gondang: Jurnal Seni Dan Budaya. https://doi.org/10.24114/gondang.v3i2.13 921

Bahruddin, Muh, Yurisma, D. Y. (2017). Adaptation Film-Based, Sequel, Prequel, and Reborn: Between Creativity and Market Domination. Proceeding The 3nd International Indonesia Forum for Asian Studies, 939-948. http://repository.dinamika.ac.id/id/eprint/ 2185/

Baxter, Leslie A. \& Babbie, E. (2018). The Basic of Communication Research. In Journal of Chemical Information and Modeling.

https://doi.org/10.1017/CBO9781107415 324.004

Bourdieu, P. (1991). On Symbolic Power. Language and Symbolic Power.

Cassirer, E. (1987). Manusia Dan Kebudayaan, Sebuah Essei Tentang Manusia (terjemahan Alsis A Nugroho (ed.)). Gramedia.

Caturwati, E. (2007). Tari Di Latar Sunda. STSI Press.

Dharsono, S. K. (2006). 829-2473-1-PB.pdf. Ornamen Jurnal Kriya Seni ISI Surakarta, Vol 3, No 1, 3. https://jurnal.isi-

ska.ac.id/index.php/ornamen/article/view /829/825

Dharsono, S. K. (2007). Budaya nusantara: kajian konsep mandala dan konsep tri 
loka terhadap pohon hayat pada batik klasik. Rekayasa Sains.

Hutapea, E. (2016). Identifikasi Diri Melalui Simbol-Simbol Komunikasi (Studi Interaksionisme Simbolik Komunitas Pemakai Narkoba di DKI Jakarta. Jurnal Bricolage, 2(1), 1-14. https://doi.org/http://dx.doi.org/10.30813/ bricolage.v2i01.825

Langer, K. S. (1976). Philosophy in a New Key A Study in the Symbolism of Reason, Rite, and Art. Harvard : University Press.

Lin, Li-Min, Tain-Dow, L. (2014). Symbolic Economy and Creative Management: Cultural and Creative Industries Urging for New Approaches. ENCATC Journal of Cultural Management and Policy, 4(1), 57-67.

https://www.encatc.org/media/394encatc-journal-vol-4-issue-1.pdf

Lynch, K. (1960). The city image and its elements. The Image of the City. https://doi.org/10.1525/sp.1960.8.3.03a0 0190

Milawaty. (2019). Watu Semar: Sebuah Refleksi Pemikiran Dan Budaya Lokal Masyarakat Sambongrejo, Bojonegoro. Jurnal Masyarakat \& Budaya, 21(3), 371-382.

https://doi.org/ttp://dx.doi.org/10.14203/j mb.v21i3.777

Munawirsazali, M. (2019). SEKENEM DAN SEKEPAT Perlindungan terhadap Perempuan dalam Tradisi Budaya Masyarakat Terpencil di Kabupaten Lombok Tengah, Nusa Tenggara Barat. Sabda: Jurnal Kajian Kebudayaan. https://doi.org/10.14710/sabda.14.1.1-13

Neuman, W. L. (2011). Social Research Methods: Qualitative and Quantitative Approaches. In Pearson Education.

Rahmanto, B. (1992). Simbolisme Dalam Seni. BASIS, Jawanisasi Kebudayaan Indonesia, 3.

Strinati, D. (2007). Popular Culture: Pengantar Menuju Budaya Populer. Jejak.

Sumardjo, J. (2003). Arkeologi budya Indonesia: pelacakan hermeneutishistoris terhadap artefakartefak kebudayaan. Qalam.

Sumiati, S., \& Girsang, L. R. (2018). KONSTRUKSI PESAN TARI
„KECAK ${ }^{c e}$ PADA MASYARAKAT

BADUNG, BALI. Bricolage: Jurnal Magister Ilmu Komunikasi. https://doi.org/10.30813/bricolage.v4i01. 1068

Yurisma, D. Y., EBW, A., \& Sachari, A. (2015). KESENIAN TRADISI REOG SEBAGAI PEMBENTUK CITRA PONOROGO.

VISUALITA.

https://doi.org/10.33375/vslt.v7i1.1081

\section{Online}

http://aryoghi26.blogspot.com

https://nabilahwitsqa.wordpress.com/2015/03/ 14/topeng-harimau-dan-hiasan-bulumerak-sosok-Warok-dan-gemblak/

https://khabarjoss.wordpress.com/galeri-foto2/atraksi-penari-Jathilan-seni-Reogponorogo-2/

http://kerajaanjaseters.blogspot.com/2015/06/kesenia n-yang-sangat-nasionalis-adalah.html

https://www.msn.com/id$\mathrm{id} /$ travel/other/mantap-kesenian-Reogponorogo-hibur-warga-myanmar/ssAAIo87O

https://news.detik.com/berita-jawa-timur/d3828590/patung-khas-bumi-Reoghiasi-perempatan-kota-ponorogo

Reogshop.blogspot.com 